UDC $615.076+579.61+577.11$

doi: https://doi.org/10.15407/ubj89.03.052

\title{
DEVELOPMENT OF THE METHOD FOR MICROBIOLOGICAL PURITY TESTING OF RECOMBINANT HUMAN INTERLEUKIN-7-BASED PRODUCT
}

\author{
O. Yu. GALKIN ${ }^{1}$, T. M. LUTSENKO',2, Yu. V. GORSHUNOV', V. V. MOTRONENKO
}

\author{
${ }^{1}$ National Technical University of Ukraine \\ "Ihor Sikorskii Kyiv Polytechnic Institute"; \\ ${ }^{2} U A$ “PRO-PHARMA” LLC, Kyiv, Ukraine; \\ e-mail: alexfbt@gmail.com
}

\begin{abstract}
The goal of the work was justification of standardization parameters of the product based on recombinant human IL-7 by "microbiological purity" parameter and development of its measurement method with consideration of the requirements of guideline documents regarding quality of medicinal products. Suitability assessment of microbiological purity testing procedures was performed. It has been established that the studied product in standard testing methods possessed antimicrobial activity against test microorganisms Basillus subtilis ATCC 6633 (on soybean casein digest agar and Sabouraud dextrose agar containing an antibiotic), Candida albicans ATCC 10231 (on soybean casein digest agar and Sabouraud dextrose agar containing an antibiotic), and possessed no antimicrobial activity against test microorganisms Staphylococcus aureus ATCC 6538 (on soybean casein digest agar) and Pseudomonas aeruginosa ATCC 9027 (on soybean casein digest agar). The efficacy of lecithin and polysorbate as substances eliminating antibacterial effect in combination with 50-fold dilution of the test sample has been suggested and proven for the purpose of antimicrobial activity neutralization. The developed total aerobic microbial count measurement procedure for the test product conforms to acceptance criteria provided by SPU (2.6.12), and can be used for its microbiological purity control.
\end{abstract}

Key words: antimicrobial activity, microbiological purity, recombinant human interleukin-7.

I nterleukin-7 (IL-7) is an immune cytokine playing a key role in T- and B-lymphocytes development and homeostasis, involved in development of dendritic cells, natural killers and cells-lymphoid tissue inducers, which are essential immunity links as well. IL-7 is capable of regulating immune system homeostasis due to the ability to maintain a balance between apoptosis and proliferation processes of thymocytes, naïve T-lymphocytes and memory cells, and thus maintaining the consistency of abundance and functional activity of these populations [1-3].

Recombinant proteins planned to be used in medicine for therapeutic or diagnostic purposes have to conform to specific requirements which differentiate them from the proteins used exclusively for research work $[4,5]$. At the same time, specific features of the use of recombinant proteins also ap- ply specific requirements regarding their standardization. One of the elements of analytical standardization of pharmaceutical products is development of the methods for testing microbiological purity.

It should be noted that this work is part of a comprehensive work on the development of recombinant human IL-7 preparation and methods of its biological standardization. At previous study steps, we have scientifically justified composition and technology of the product based on recombinant human IL-7 in the form of nasal spray (drops); quality profile of such product $[6,7]$, its biological (specific) standardization methods have been developed $[8,9]$.

The goal of the work was scientific justification of standardization parameters of the product based on recombinant human IL-7 in the form of nasal spray (drops) by "microbiological purity" parameter and development of the method for this parameter

(C) 2017 Galkin O. Yu. et al. This is an open-access article distributed under the terms of the Creative Commons Attribution License, which permits unrestricted use, distribution, and reproduction in any medium, provided the original author and source are credited. 
measurement with consideration of the requirements of guideline documents regarding quality of medicinal products.

\section{Materials and Methods}

Nutrient media. Nutrient media (NM) in accordance with requirements of SPU (State Pharmacopeia of Ukraine) 2.0 (2.6.12, 2.6.13) were used during the tests. The NM were prepared from dry nutrient media or individual ingredients; each nutrient medium batch was tested for sterility, growth and, when needed, inhibitory and indicator properties. The media list, characteristics, and media suitability control results are shown in Table 1.

Test microorganisms. Test microorganisms in accordance with requirements of SPU 2.0 (2.6.12, 2.6.13) were used during the testing. The list of test microorganisms is shown in Table 2 (source of origin: Ukrainian collection of microorganisms).

The storage of test microorganisms was performed in accordance with for Quality Control of Medicinal Products by Microbiological Parameters. Procedure of Receipt, Accounting, Storage and Maintenance of Microbial Test Strains

Test microorganism suspensions, prepared as detailed below, were used as inoculum for the testing. Test microorganisms were cultured, each separately, in an appropriate nutrient medium. Bacterial test strains were cultured in soybean casein digest broth at temperatures from 30 to $35^{\circ} \mathrm{C}$ for 18 to $24 \mathrm{~h}$. Fungal test strains were cultured at the surface of Sabouraud dextrose agar at temperatures from 20 to $25{ }^{\circ} \mathrm{C}$. Test microorganism Candida albicans was cultured for 2 days, and test microorganism Aspergillus brasiliensis (niger) was cultured for 5-7 days till receipt of well-developed spores.
In order to prepare the starting suspensions of bacterial test strains, the broth cultures were diluted using buffer solution with sodium chloride and peptone $\mathrm{pH} 7.0$ till formation of the suspension containing $10^{3}$ to $10^{4} \mathrm{CFU} / \mathrm{ml}$ of test microorganism.

In order to prepare the starting suspension of test microorganism C. albicans, the culture was washed from the surface of Sabouraud dextrose agar using buffer solution with sodium chloride and peptone $\mathrm{pH}$ 7.0, and diluted with the same solvent till formation of the suspension containing $10^{3}$ to $10^{4} \mathrm{CFU} / \mathrm{ml}$ of test microorganism.

In order to prepare the starting suspension of test microorganism A. brasiliensis (niger), the culture was washed from the surface of Sabouraud dextrose agar using buffer solution with sodium chloride and peptone $\mathrm{pH} 7.0$, which contained $0.05 \%$ of polysorbate-80, and diluted using buffer solution with sodium chloride and peptone $\mathrm{pH} 7.0$ till formation of the suspension containing $10^{3}$ to $10^{4} \mathrm{CFU} / \mathrm{ml}$ of test microorganism.

Suitability testing of total aerobic microbial count measurement procedure. Total aerobic microbial count measurement procedure conforms to the requirements of SPU 2.0 (2.6.12).

Sample preparation: Transfer $10 \mathrm{ml}$ of the product into a sterile volumetric vessel, make up the volume to $100 \mathrm{ml}$ with sterile buffer solution containing sodium chloride and peptone $\mathrm{pH}$ 7.0, and mix thoroughly (sample A); transfer $10 \mathrm{ml}$ of the product into a sterile volumetric vessel, make up the volume to $200 \mathrm{ml}$ with sterile buffer solution containing sodium chloride and peptone $\mathrm{pH} 7.0$, and mix thoroughly (sample B). For total aerobic microbial count (TAMC) measurement, inoculate $1 \mathrm{ml}$ portions of the prepared sample B via double-layer technique

Ta b le 1. Nutrient media used for testing the procedure suitability

\begin{tabular}{|l|l|}
\hline \multicolumn{1}{|c|}{ Medium name } & \multicolumn{1}{c|}{ Purpose } \\
\hline Soybean casein digest broth & $\begin{array}{l}\text { Preparation of bacterial test strains, enrichment medium for detection of } \\
\text { Staphylococcus aureus, Pseudomonas aeruginosa }\end{array}$ \\
\hline Soybean casein digest agar & TAMC $^{1}$ measurement \\
\hline Sabouraud dextrose agar & Preparation of fungal test strains \\
\hline $\begin{array}{l}\text { Sabouraud dextrose agar } \\
\text { containing an antibiotic }\end{array}$ & TYMC $^{2}$ measurement \\
\hline Mannitol salt agar & Differential diagnostic medium for Staphylococcus aureus isolation \\
\hline Cetrimide agar & Differential diagnostic medium for Pseudomonas aeruginosa isolation \\
\hline
\end{tabular}

Remarks: ${ }^{1}$ TAMC - total aerobic microbial count; ${ }^{2}$ TYMC - total yeast/mold count. 
Ta ble 2. Microorganisms used for testing the procedure suitability

\begin{tabular}{|l|c|l|}
\hline Name of test microorganism & Strain number & \multicolumn{1}{|c|}{ Purpose } \\
\hline Bacillus subtilis & ATCC 6633 & Suitability testing of TAMC measurement procedure \\
\hline Staphylococcus aureus & ATCC 6538 & $\begin{array}{l}\text { Suitability testing of TAMC measurement procedure, } \\
\text { suitability testing of the procedure for identification } \\
\text { of individual microbial species }\end{array}$ \\
\hline Pseudomonas aeruginosa & ATCC 9027 & $\begin{array}{l}\text { Suitability testing of TAMC measurement procedure, } \\
\text { suitability testing of the procedure for identification } \\
\text { of individual microbial species }\end{array}$ \\
\hline Candida albicans & ATCC 10231 & $\begin{array}{l}\text { Suitability testing of TAMC and TYMC measurement } \\
\text { procedure }\end{array}$ \\
\hline Aspergillus brasiliensis (niger) & ATCC 16404 & $\begin{array}{l}\text { Suitability testing of TAMC and TYMC measurement } \\
\text { procedure }\end{array}$ \\
\hline
\end{tabular}

into each of two Petri dishes with soybean casein digest agar. For total yeast and mold count (TYMC) measurement, inoculate $1 \mathrm{ml}$ portions of the prepared sample A via double-layer technique into each of two Petri dishes with Sabouraud dextrose agar containing an antibiotic.

Inoculum preparation. For each of test microorganisms B. subtilis ATCC 6633, S. aureus ATCC 6538, P. aeruginosa ATCC 9027, C. albicans ATCC 10231 and A. brasiliensis (niger) ATCC 16404, starting suspension of the monoculture was prepared, which contained $10^{3} \mathrm{l}$ to $10^{4} \mathrm{CFU} / \mathrm{ml}$, as mentioned above. The suspension was used as inoculums during suitability testing of TAMC and TYMC measurement procedure.

Procedure suitability testing. The samples were prepared as specified by the method detailed above, using the sterile solvent. Five individual $10 \mathrm{ml}$ portions were taken from the prepared sample B. Each portion was inoculated with monoculture of one of test microorganisms $B$. subtilis, $S$. aureus, $P$. aeruginosa, C. albicans, A. brasiliensis (niger), for which $0.1 \mathrm{ml}$ of inoculums (containing $10^{3}$ to $10^{4} \mathrm{CFU} / \mathrm{ml}$ ) were added to $10 \mathrm{ml}$ of the sample.

In control experiment $0.1 \mathrm{ml}$ of the inoculum of the same microorganism was added to $10 \mathrm{ml}$ of sterile solvent. Each inoculated sample (experimental and control) in the amount of $1 \mathrm{ml}$ was plated into 2 Petri dishes as specified in the procedure. Soybean casein digest agar was used for plating the samples. The inoculations in soybean casein digest agar were incubated at temperatures from 30 to $35^{\circ} \mathrm{C}$. Incubation of inoculations containing bacterial test strains was performed within 3 days, and incubation of inoculations containing fungal test strains was per- formed within 5 days. Two individual $10 \mathrm{ml}$ portions were taken from the prepared sample A. Each portion was inoculated with monoculture of one of test microorganisms C. albicans, A. brasiliensis (niger), for which $0.1 \mathrm{ml}$ of the inoculums (containing $10^{3}$ to $10^{4} \mathrm{CFU} / \mathrm{ml}$ ) were added to $10 \mathrm{ml}$ of the sample. In control experiment $0.1 \mathrm{ml}$ of the inoculum of the same microorganism was added to $10 \mathrm{ml}$ of sterile solvent; $1 \mathrm{ml}$ of each inoculated sample (experimental and control) was plated into 2 Petri dishes as specified in the procedure. Sabouraud dextrose agar containing an antibiotic was used for plating the samples. Inoculations in Sabouraud dextrose agar were incubated at temperatures from 20 to $25^{\circ} \mathrm{C}$ for 5 days.

To obtain statistically significant results, the testing was performed for three different product batches.

\section{Results and Discussion}

Suitability of total aerobic microbial count measurement procedure. At the first stage of the work, we have carried out suitability testing of total aerobic microbial count measurement procedure, included to the Quality Control Methods draft for recombinant human IL-7 product in the form of nasal spray (drops).

Upon inoculation into NM from the product dilution $1: 10$ in phosphate buffer solution with sodium chloride and peptone $\mathrm{pH}$ 7.0, the product possessed antimicrobial activity against test microorganisms B. subtilis ATCC 6633 (in soybean casein digest agar and Sabouraud dextrose agar containing an antibiotic), C. albicans ATCC 10231 (in soybean casein digest agar and Sabouraud dextrose agar con- 
taining an antibiotic). It has to be mentioned that, according to the recommendations of SPU 2.0 (2.6.12), during the procedure of suitability testing using plate inoculation method, mean arithmetic value of the number of colonies obtained in the presence of test sample and in the absence of test sample (in the control experiment) for each test microorganism has to differ no more than twice.

The obtained results (Table 3) stimulated us to study the potential of elimination of the product antimicrobial effect against microorganisms in soybean casein digest agar and Sabouraud dextrose agar containing an antibiotic, using direct inoculation method.

If growth inhibition of test microorganism is observed (CFU number decrease more than twice), justification should be presented, and the standard procedure should be modified for the purpose of obtaining the probable test results. Literature [4] describes the following approaches to elimination and/ or neutralization of antimicrobial activity: first, the increase of the volume of solvent or nutrient medium; second, addition of specific or non-specific inactivators to the solvent; third, use of the membrane filtration method. A combination of the mentioned approaches can be used. The most adequate approach, in our opinion, is the use of neutralizers; it does not require additional testing steps and involvement of additional material and technical means, which is of special importance for routine testing of product batches. In view of the product formulation (including nipagin as a preservative) and with consideration of the literature data and out own experience [4, 9-13], we focused on the compounds potentially exerting neutralizing effect against parabens - lecithin and polysorbate.

Thus, non-specific inactivators polysorbate- 80 and lecithin, which were added to the solvent and nutrient medium, as well as dilution method were used for neutralization of antimicrobial effects. Phosphate buffer solution (PBS) with sodium chloride and peptone $\mathrm{pH} 7.0$ and neutralizing fluids (NF), different by polysorbate- 80 and lecithin concentrations, were used as solvents for the sample preparation.

During the study of antimicrobial effect neutralization potential, the product test samples were prepared using a sterile solution, and monoculture suspension of one of the following test microorganisms: B. subtilis ATCC 6633 or C. albicans ATCC 10231, was added to the sample so that $1 \mathrm{ml}$ of the inoculated sample contained about $100 \mathrm{CFU}$ of test microorganism. In the control experiment, the same quantity of microorganism monoculture suspension was added to the sterile solvent. Each inoculated sample (experimental and control) in the amount of $1 \mathrm{ml}$ was plated into 2 Petri dishes with soybean casein digest agar. Incubation of inoculations was performed at temperatures from 30 to $35^{\circ} \mathrm{C}$ for no more than 3 days, and the number of colonies grown on NM was calculated.

Ta b le 3. Results of suitability testing of total aerobic microbial count measurement procedure in the product (batch 0116)

\begin{tabular}{|c|c|c|c|c|}
\hline \multirow{2}{*}{ Test microorganism } & \multicolumn{2}{|c|}{$\begin{array}{l}\text { Mean CFU value of test } \\
\text { microorganism on Petri dishes }\end{array}$} & \multirow{2}{*}{$\begin{array}{l}\text { Ratio of mean } \\
\text { CFU value in } \\
\text { the absence and } \\
\text { in the presence } \\
\text { of the product }\end{array}$} & \multirow{2}{*}{ NM name } \\
\hline & $\begin{array}{l}\text { In the presence } \\
\text { of product }\end{array}$ & $\begin{array}{l}\text { In the absence } \\
\text { of product }\end{array}$ & & \\
\hline \multicolumn{5}{|c|}{ TAMC measurement } \\
\hline B. subtilis ATCC 6633 & 13 & 27 & 2.08 & \multirow{5}{*}{$\begin{array}{l}\text { Soybean casein } \\
\text { digest agar }\end{array}$} \\
\hline S. aureus ATCC 6538 & 54 & 60 & 1.11 & \\
\hline P. aeruginosa ATCC 9027 & 83 & 84 & 1.01 & \\
\hline C. albicans ATCC 10231 & 18 & 43 & 2.39 & \\
\hline A. brasiliensis ATCC 16404 & 9 & 26 & 2.89 & \\
\hline \multicolumn{5}{|c|}{ TYMC measurement } \\
\hline C. albicans ATCC 10231 & 20 & 46 & 2.30 & \multirow{2}{*}{$\begin{array}{l}\text { Sabouraud dextrose } \\
\text { agar containing } \\
\text { an antibiotic }\end{array}$} \\
\hline A. brasiliensis ATCC 16404 & 15 & 44 & 2.93 & \\
\hline
\end{tabular}


Table 4. Results of studying the product antimicrobial activity neutralization potential

\begin{tabular}{|c|c|c|c|c|}
\hline \multirow[b]{2}{*}{ Dilution } & \multirow[b]{2}{*}{ Solvent } & \multicolumn{3}{|c|}{ Mean CFU count on Petri dishes* } \\
\hline & & $\begin{array}{c}\text { B. subtilis } \\
\text { ATCC } 6633\end{array}$ & $\begin{array}{c}\text { C. albicans } \\
\text { ATCC } 10231\end{array}$ & $\begin{array}{c}\text { A. brasiliensis } \\
\text { ATCC } 16404\end{array}$ \\
\hline \multicolumn{5}{|c|}{ Soybean casein digest agar } \\
\hline $1: 10$ & \multirow{4}{*}{$\begin{array}{l}\text { PBS with sodium } \\
\text { chloride and } \\
\text { peptone, pH } 7.0\end{array}$} & 12 & 20 & 11 \\
\hline $1: 20$ & & 11 & 22 & 13 \\
\hline $1: 50$ & & 18 & 18 & 17 \\
\hline Control & & 30 & 45 & 35 \\
\hline $1: 10$ & \multirow{4}{*}{$\begin{array}{c}\text { NF with } 30 \mathrm{~g} / \mathrm{l} \\
\text { polysorbate-80, } \\
3 \mathrm{~g} / \mathrm{l} \text { lecithin }\end{array}$} & 13 & 10 & 12 \\
\hline $1: 20$ & & 15 & 12 & 15 \\
\hline $1: 50$ & & 21 & 20 & 24 \\
\hline Control & & 32 & 43 & 31 \\
\hline $1: 10$ & \multirow{4}{*}{$\begin{array}{c}\text { NF with } 50 \mathrm{~g} / \mathrm{l} \\
\text { polysorbate-80, } \\
5 \mathrm{~g} / \mathrm{l} \text { lecithin }\end{array}$} & 14 & 21 & 12 \\
\hline $1: 20$ & & 17 & 25 & 31 \\
\hline $1: 50$ & & 29 & 46 & 30 \\
\hline Control & & 27 & 44 & 30 \\
\hline \multicolumn{5}{|c|}{ Sabouraud dextrose agar containing an antibiotic } \\
\hline $1: 10$ & \multirow{4}{*}{$\begin{array}{c}\text { NF with } 50 \text { g/l } \\
\text { polysorbate-80, } \\
5 \mathrm{~g} / \mathrm{l} \text { lecithin }\end{array}$} & Not performed & 12 & 11 \\
\hline $1: 20$ & & Not performed & 30 & 20 \\
\hline $1: 50$ & & Not performed & 44 & 34 \\
\hline Control & & Not performed & 42 & 37 \\
\hline
\end{tabular}

Remark: * the data of three consecutive experiments are presented $(P<0.05)$

Additionally, it was suggested to use the dilution $1: 50$, which assures partial neutralization of antimicrobial effects, and receipt of reliable results of viable cells calculation. Dilution increase to $1: 100$ is not correct, as in case of using such dilution during control of the product containing maximum permissible microbial count -1000 , growth of no more than 10 colonies will be observed on each dish, which essentially increases the risk to obtain either false positive or false negative test results, as well as affects reliability of the obtained results. The results of studies on neutralization of the product antimicrobial effects (Table 4 and Fig. 1-2) confirm that the suggested procedure allows us to eliminate the product antimicrobial activity effectively in antimicrobial purity testing conditions.

The product microbiological purity standardization has been established in accordance with requirements of SPU 2.0 (5.1.4) as for non-sterile medicinal products for nasal use: the product may contain total aerobic microbial count (TAMC) no more than $10^{2} \mathrm{CFU} / \mathrm{ml}$, total yeast and mold count
(TYMC) no more than $10^{1} \mathrm{CFU} / \mathrm{ml}$, the presence of Staphylococcus aureus in $1 \mathrm{ml}$ and the presence of Pseudomonas aeruginosa in $1 \mathrm{ml}$ is not permitted.

In order to unify the product microbiological purity testing by various parameters during TAMC and TYMC measurement, as well as during tests for detection of individual microbial species (S. aureus, $P$. aeruginosa), we have suggested to use the same solvent (neutralizing fluid) with the same product dilution $(1: 50)$. It has been established that, in suggested testing conditions the product does not exert antimicrobial effects against test microorganisms S. aureus ATCC 6538 (on soybean casein digest agar) and P. aeruginosa ATCC 9027 (on soybean casein digest agar).

Thus, the conducted studies are indicative of the fact that the developed procedure of total aerobic microbial count measurement for the test product conforms to the acceptance criteria of SPU 2.0 (2.6.12) and can be used in microbiological purity control. 

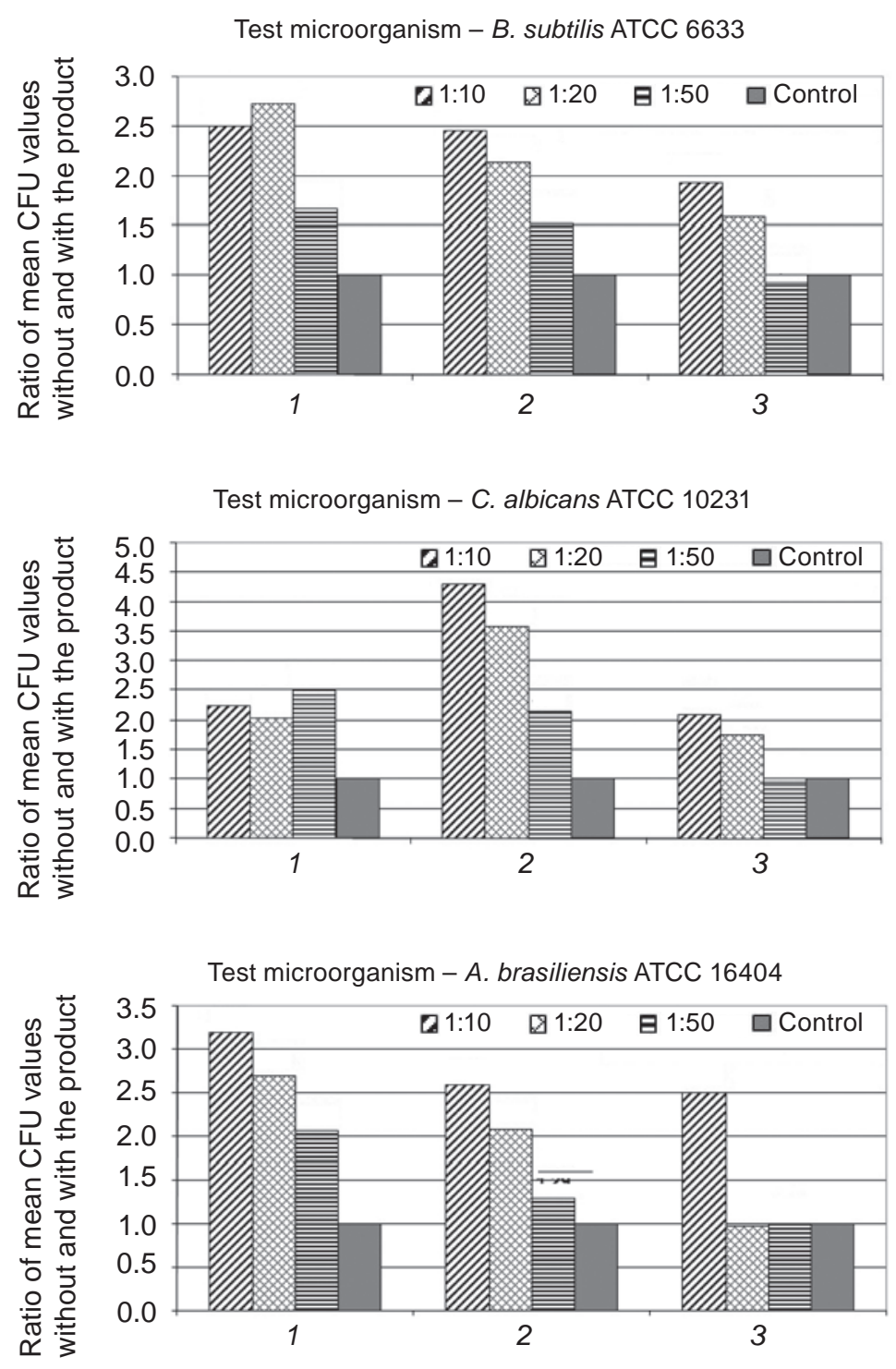

Fig. 1. Results of studies of antimicrobial effect neutralization using various test microorganisms on soybean casein agar. Solvents variants: 1 - PBS with sodium chloride and peptone, pH 7.0; 2 - NF with $30 \mathrm{~g} / \mathrm{l}$ polysorbate-80, $3 \mathrm{~g} / \mathrm{l}$ lecithin; 3 - NF with $50 \mathrm{~g} / \mathrm{l}$ polysorbate- $80,5 \mathrm{~g} / \mathrm{l}$ lecithin

Scientific standardization of recombinant human interleukin-7 based product in the form of nasal spray has been performed: the product may contain total aerobic microbial count (TAMC) no more than $10^{2} \mathrm{CFU} / \mathrm{ml}$, total yeast and mold count (TYMC) no more than $10^{1} \mathrm{CFU} / \mathrm{ml}$; the presence of $S$. aureus in $1 \mathrm{ml}$ is not permitted, the presence of $P$. aeruginosa in $1 \mathrm{ml}$ is not permitted. Suitability assessment of microbiological purity testing procedures was performed. It has been established that the test product in standard testing methods possessed antimicrobial activity against test microorganisms $B$. subtilis ATCC 6633 (on soybean casein digest agar and
Sabouraud dextrose agar containing an antibiotic), C. albicans ATCC 10231 (on soybean casein digest agar and Sabouraud dextrose agar containing an antibiotic), and possessed no antimicrobial activity against test microorganisms S. aureus ATCC 6538 (on soybean casein digest agar) and P. aeruginosa ATCC 9027 (on soybean casein digest agar). The efficacy of lecithin and polysorbate as substances eliminating antibacterial effect in combination with 50 -fold dilution of the test sample has been suggested and proven for the purpose of antimicrobial activity neutralization. The developed procedure of total aerobic microbial count measurement for the test 


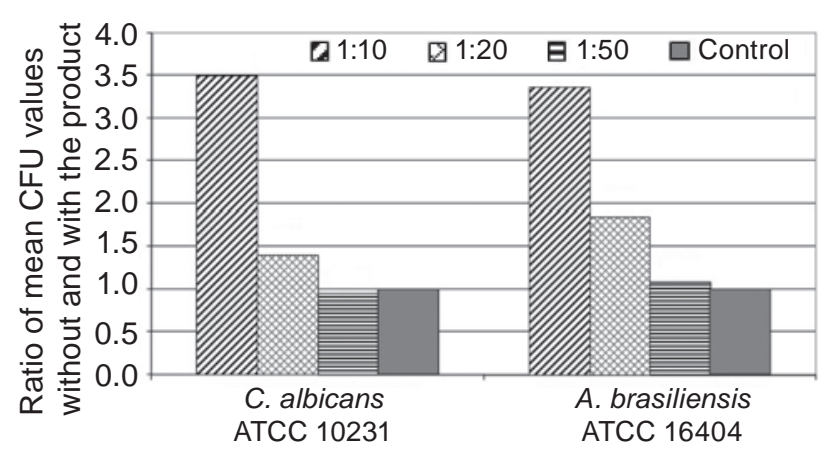

Fig. 2. Results of studies of antimicrobial effect neutralization using various test microorganisms on Sabouraud dextrose agar. Solvent: NF with $50 \mathrm{~g} / \mathrm{l}$ polysorbate- $80,5 \mathrm{~g} / \mathrm{l}$ lecithin

product conforms to acceptance criteria provided by SPU 2.0 (2.6.12), and can be used for its microbiological purity control.

\section{РОЗРОБКА МЕТОДУ \\ ВИПРОБУВАННЯ МІКРОБІОЛОГІЧНОЇ ЧИСТОТИ ПРЕПАРАТУ НА ОСНОВІ РЕКОМБІНАНТНОГО ІНТЕРЛЕЙКІНУ-7 ЛЮДИНИ}

О. Ю. Галкін ${ }^{1}$, Т. М. Луиенко ${ }^{1,2}$, Ю. В. Горшунов ${ }^{1}$ В. В. Мотроненко ${ }^{1}$

${ }^{1}$ Національній технічний університет України «Київський політехнічний інститут імені Ігоря Сікорського»; ${ }^{2}$ ТОВ «УА «ПРО-ФАРМА», Київ, Україна; e-mail: alexfbt@gmail.com

Метою роботи було обгрунтування параметрів стандартизації препарату на основі рекомбінантного інтерлейкіну-7 людини за показником «мікробіологічна чистота» та розробка методу визначення цього показника 3 урахуванням вимог керівних документів щодо якості лікарських засобів. Проведено оцінку придатності методик визначення мікробіологічної чистоти. Встановлено, що досліджуваний препарат за стандартних методів дослідження виявляв антимікробну активність по відношенню до тест-мікроорганізмів Bacillus subtilis ATCC 6633 (на соєво-казеїновому агарі та Сабуро-декстрозному агарі з антибіотиком), Candida albicans ATCC 10231 (на соєвоказеїновому агарі та Сабуро-декстрозному агарі 3 антибіотиком) і не виявляв антимікробну дію відносно тест-мікроорганізмів Staphylococcus aureus ATCC 6538 (на соєво-казеїновому агарі) та Pseudomonas aeruginosa ATCC 9027 (на соєво-казеїновому агарі). 3 метою нейтралізації антимікробної активності було запропоновано та доведено ефективність використання лецитину та полісорбату як речовин, що знімають антибактеріальний ефект за розведення досліджуваного зразка у 50 разів. Розроблена методика визначення загального числа життєздатних мікроорганізмів для досліджуваного препарату, за вимогою ДФУ, відповідає критеріям придатності та може бути використана для контролю його мікробіологічної чистоти.

К л ю ч о в активність, мікробіологічна чистота, рекомбінантний інтерлейкін-7 людини.

\section{РАЗРАБОТКА МЕТОДА \\ ИСПЫТАНИЯ \\ МИКРОБИОЛОГИЧЕСКОЙ \\ ЧИСТОТЫ ПРЕПАРАТА НА \\ ОСНОВЕ РЕКОМБИНАНТНОГО ИНТЕРЛЕЙКИНА-7 ЧЕЛОВЕКА}

А. Ю. Галкин ${ }^{1}$, Т. Н. Луценко ${ }^{1,2}$, Ю. В. Горшунов 1 В. В. Мотроненко

${ }^{1}$ Национальный технический университет Украины «Киевский политехнический институт имени Игоря Сикорского»;

${ }^{2} \mathrm{OOО} \mathrm{«УА} \mathrm{«ПРО-ФАРМА»,} \mathrm{Киев,} \mathrm{Украина;}$ e-mail: alexfbt@gmail.com

Целью работы было обоснование параметров стандартизации препарата на основе рекомбинантного интерлейкина-7 человека по показателю «микробиологическая чистота» и разработка метода определения этого показателя с учетом требований руководящих документов по качеству лекарственных средств. Проведена оценка пригодности методик определения микробиологической чистоты. Установлено, что исследуемый препарат при стандартных методах исследования проявлял антимикробную активность в отношении тест-микроорганизмов Bacillus subtilis ATCC 6633 (на соево-казеиновом агаре и Сабуро-декстрозном агаре, содержащем антибиотик), Candida albicans ATCC 10231 (на соево-казеиновом агаре и Сабуро-декстрозном агаре, содержащем антибиотик) и не про- 
являл антимикробное действие по отношению к тест-микроорганизмам Staphylococcus aureus ATCC 6538 (на соево-казеиновом агаре) и Pseudomonas aeruginosa ATCC 9027 (на соевоказеиновом агаре). С целью нейтрализации антимикробной активности было предложено использование лецитина и полисорбата и доказана их эффективность как веществ, снимающих антибактериальный эффект при разведении исследуемого образца в 50 раз. Разработанная методика определения общего числа жизнеспособных микроорганизмов для исследуемого препарата, предъявляемым ГФУ, соответствует критериям пригодности и может быть использована при контроле его микробиологической чистоты.

Ключевы е слов а: антимикробная активность, микробиологическая чистота, рекомбинантный интерлейкин-7 человека.

\section{References}

1. Fry TJ, Mackall CL. Interleukin-7: from bench to clinic. Blood. 2002; 99(11): 3892-3904.

2. Gilchuk PV. Evaluation of renaturation methods for industrial obtaining of recombinant proteins from Escherichia coli inclusion bodies in biologically active form”. Biopolym Cell. 2004; 20(3): 182-192. (In Russian).

3. Slyvka AV, Okunev OV. Molecular mechanisms of versatile biological activity of interleukin-7 . Biopolym Cell. 2014; 30(5): 349-357.

4. Galkin OYu, Shyrobokov VP, Grygorenko AA, Dugan O, Lutsenko TM, Komar AG. Biotechnological bases of creation of tools for serological diagnosis of infectious and non-infectious diseases. Ed. Shyrobokov VP. Kiev, Ukraine: NTUU “KPI”, 2015; 204 p. (In Ukrainian).

5. State Pharmacopoeia of Ukraine: in 3 volumes $2^{\text {nd }}$ edition. Kh.: Pharmacopoeia Ukrainian Center for Quality of Medicines. 2015; 1: 1128. (In Ukrainian).
6. Lutsenko TM, Andryukova LM, Fetisova OG, Marintsova NG, Galkin OYu. Development of composition and technology of preparation based on recombinant human interleukin-7. Visnyk Nat Univ "Lvivska Politekhnika”. 2016; (841): 174-180. (In Ukrainian).

7. Lutsenko TM, Galkin OYu, Karpenko OYa, Duhan OM. Substantiation of parameters for standardization of drugs based on recombinant human interleukin-7. Visnyk Nat Univ "Lvivska Politekhnika”. 2015; (812): 175-183. (In Ukrainian).

8. Lutsenko TM, Starosyla DB, Rybalko SL, Galkin OYu. Methods for assessing biological activity of recombinant human interleukin-7, and stability studies of the drug based on it. Naukovi Visti NTUU “KPI”. 2016; 3: 48-54. (In Ukrainian).

9. Lutsenko TN, Kovalenko MV, Galkin OYu. Validation of biological activity testing procedure of recombinant human interleukin-7. Ukr Biochem J. 2017; 89(1): 82-89.

10. Gunar OV, Builova IA. Microbiological Quality Control of Biotechnological Pharmaceuticals. Pharmac Chem J. 2016; 50(2): 108-113. (In Ukrainian).

11. Gunar OV. Determination and neutralization of antimicrobial action of drugs. Farmaciya. 2004; (3): 5-7. (In Russian).

12. Gunar OV, Kalamova NI, Evtushenko NS. Determination of antimicrobial action of drugs practical approaches. Farmaciya. 2002; (2): 4-7. (In Russian).

13. Zhemerova EG, Dunay EV, Galkin AYu, Mulder L, van Hemert S. Development of quality control methods and research of probiotic preparation for the treatment and prevention of allergy and dysbiosis. Ukr J Clin Lab Med. 2012; 7(4): 169-174. 